\title{
Effect of Rates of Single Superphosphate added to Poultry Manure on Popcorn (Zea mays everta) Production in Jos, Plateau State.
}

\author{
Ali, E.T ${ }^{1}$ and F. Ibrahim ${ }^{2}$ \\ Department of Soil Science, College of Agronomy, University of Agriculture, Makurdi - Nigeria \\ Author for correspondence. Email: terver247@gmail.com
}

\begin{abstract}
Field studies were conducted at the Teaching and Research Farm of Federal College of Land Resources Technology, Kuru-Jos in 2013 and 2014 cropping seasons. The effect of rates of single superphosphate fertilizer to be added to poultry manure for Popcorn Zea mays everta Production in Jos was investigated. The experiment was laid out in a Randomized Complete Block Design with four replicates. Five treatments were used: $20 \mathrm{th} \mathrm{ha}^{-1}$ Poultry manure $(\mathrm{PM})+\mathrm{O} \mathrm{kg} \mathrm{P}_{2} \mathrm{O}_{5} \mathrm{ha}^{-1}$ (control), $20 \mathrm{tha^{-1 }} \mathrm{PM}+20$ kg $\mathrm{P}_{2} \mathrm{O}_{5} \mathrm{ha}^{-1}, 20 \mathrm{tha^{-1 }} \mathrm{PM}+40 \mathrm{~kg} \mathrm{P}_{2} \mathrm{O}_{5} \mathrm{ha}^{-1}, 20 \mathrm{tha^{-1 }} \mathrm{PM}+$ $60 \mathrm{~kg} \mathrm{P}_{2} \mathrm{O}_{5} \mathrm{ha}^{-1}$ and $20 \mathrm{tha}+10 \mathrm{~kg} \mathrm{P}_{2} \mathrm{O}_{5} \mathrm{ha}^{-1}$. The results revealed that the grain yield of Popcorn were significantly $(P<0.05)$ affected by the treatments in both seasons. The application of $20 \mathrm{th} \mathrm{h}^{-1} \mathrm{PM}+80 \mathrm{~kg} \mathrm{P}_{2} \mathrm{O}_{5} \mathrm{ha}^{-1}$ gave the highest grain yield in both seasons, also the soil properties at the end of the experiments improved in terms of organic matter, total nitrogen and exchangeable cations. Hence $20 t$ $\mathrm{ha}^{-1} \mathrm{PM}+80 \mathrm{~kg} \mathrm{P}_{2} \mathrm{O}_{5} \mathrm{ha}^{-1}$ is recommended for Popcorn production in Kuru and its environs.
\end{abstract}

Keywords - Single Superphosphate, Poultry manure, Popcorn.

\section{INTRODUCTION}

Popcorn (Zea may everta) just as the ordinary maize is an important crop that has world significance as it is a good source of food not only for humans but also for livestock (Akintola, 1997). In many regions, it is consumed as a vegetable although it is a grain crop. In Nigeria it is mainly consumed as a snack. The grains are rich in vitamins $\mathrm{A}, \mathrm{C}$ and $\mathrm{E}$, carbohydrates and essential minerals and contain $9 \%$ protein. They also rich in dietary fibres which are food source of energy (IITA, 2007),

Popcorn being a cereal is a very high nutrient demanding crop, requiring adequate nutrient for maximum performance. Among the several other factors which cause a declined in corn yield is soil degradation from intensive alteration are continuous application of high rates of fertilizers which may cause nutrient imbalance and limit the uptake of other essential nutrients, thus limiting the crop performance (Obi, 1991).

Phosphorus is an essential constituents of numerous substance involved in biochemical reactions including photosynthesis and respirations. It is a major component of adenosine diphosphate (ADP) and adenosine triphosphate (ATP). These are used to supply energy for many biochemical reactions in plants and animals. Phosphorus levels in soil can be used as a guide to indicate whether phosphorus fertilizer is required for plant growth (Moody and Balland, 1999).

The objective of this study is therefore to establish the correct rate of SSP to be added to poultry manure for popcorn production in Jos.

\section{MATERIALS AND METHODS}

Field trials were conducted at the Teaching and Research Farm of Federal College of Land Resources Technology, Kuru in 2013 and 2014 cropping seasons. The site which falls between Longitude $8^{0} 5^{\prime}-9^{0} 5^{\prime} \mathrm{E}$ and Latitude $9^{0} 5^{\prime}-10^{0}$ $\mathrm{N}$, at an elevation of $1400 \mathrm{~m}$ above sea level. The effect of rates of single superphosphate (SSP) fertilizer to be added to poultry manure for Popcorn (Zea mays everta) production was investigated. The experiments were laid out in a Randomised Complete Block Design (RCDD), with four replications. Five treatments were used: $20 \mathrm{t} \mathrm{ha}^{-1}$ Poultry manure $(\mathrm{PM})+\mathrm{O} \mathrm{kg} \mathrm{P}_{2} \mathrm{O}_{5} \mathrm{ha}^{-1}$ (control), $20 \mathrm{tha}^{-1} \mathrm{PM}+20$ kg ha- ${ }^{-1} \mathrm{P}_{2} \mathrm{O}_{5}, 20 \mathrm{tha}^{-1} \mathrm{PM}+40 \mathrm{~kg} \mathrm{ha}^{-1} \mathrm{P}_{2} \mathrm{O}_{5}, 20 \mathrm{t} \mathrm{ha}^{-1} \mathrm{PM}+$ $60 \mathrm{~kg} \mathrm{ha}^{-1} \mathrm{P}_{2} \mathrm{O}_{5}$ and $20 \mathrm{tha}^{-1}+80 \mathrm{~kg} \mathrm{ha}^{-1} \mathrm{P}_{2} \mathrm{O}_{5}$ were used with each plot size measuring $3 \mathrm{~m} \times 3 \mathrm{~m}\left(9 \mathrm{~m}^{2}\right)$. The yield parameters considered were number of cobs and grain weight, the data collected was subjected to Analysis of Variance (ANOVA) and means were separated using Fishers Least Significant Difference (FLSD). 
Soil samples were collected from the plough layer $(0-15$ $\mathrm{cm})$ at the beginning of the experiments and after harvest of the popcorn. The samples were analyzed for, $\mathrm{pH}, \mathrm{OM}$, total $\mathrm{N}$, available $\mathrm{P}$, exchangeable cations $(\mathrm{Mg}, \mathrm{Ca}, \mathrm{K}$ and $\mathrm{Na}$ ) and cations exchange capacity (CEC).

\section{RESULTS AND DISCUSSION}

The chemical properties of the soil at the experimental site before application of treatments and after harvest of popcorn for the two cropping seasons are shown in Tables 1 and 2. The $\mathrm{pH}$ values in both seasons were below the slightly acidic range (5.5 - 6.5) considered option for normal growth of most crops (Kamprath, 1970; Bruce and Rayment, 1982). This low pH may likely be the cause of the generally low nutrient status of the experimental site in the both seasons (Brady, 1984; McKenzie et al., 2004).

The soil analysis results also revealed that organic matter $(\mathrm{OM})$, trial $\mathrm{N}$, available $\mathrm{P}$ seasons and CEC slightly improved in all the plots in both seasons at the end of the experiments. This could be as a result of the organic material introduced into the soil in form of poultry manure which also serves as a source of nutrients and accumulation humus.

The number of cobs and grain yield were significantly $(\mathrm{P}<0.05)$ affected by the application of treatments in both seasons (Table 3). In 2013, the highest numbers of cobs (38 cobs) were obtained with $20 \mathrm{t} \mathrm{ha}^{-1} \mathrm{PM}+60 \mathrm{~kg} \mathrm{ha}^{-1} \mathrm{P}_{2} \mathrm{O}_{5}$ and $20 \mathrm{t} \mathrm{ha}^{-1} \mathrm{PM}+60 \mathrm{~kg} \mathrm{ha}^{-1} \mathrm{P}_{2} \mathrm{O}_{5}$ while the least was $20 \mathrm{t} \mathrm{ha}^{-1}$ $\mathrm{PM}+0 \mathrm{~kg} \mathrm{ha}^{-1} \mathrm{P}_{2} \mathrm{O}_{5}$ (15 cobs). In terms of grain yield $20 \mathrm{t}$ $\mathrm{ha}^{-1} \mathrm{PM}+80 \mathrm{~kg} \mathrm{ha}^{-1} \mathrm{P}_{2} \mathrm{O}_{5}$ gave the highest yield of 1.94 tons $\mathrm{ha}^{-1}$ followed by 20 tons ha-1 $\mathrm{PM}+60 \mathrm{~kg} \mathrm{ha}^{-1} \mathrm{P}_{2} \mathrm{O}_{5}$. In 2014, a similar trend was observed, with the highest number of cobs obtained with $20 \mathrm{t} \mathrm{ha}^{-1} \mathrm{PM}+80 \mathrm{~kg} \mathrm{ha}^{-1} \mathrm{P}_{2} \mathrm{O}_{5}$ (36 cobs) followed by $20 \mathrm{tha}^{-1} \mathrm{PM}+60 \mathrm{~kg} \mathrm{ha}^{-1} \mathrm{P}_{2} \mathrm{O}_{5}$ (35 cobs). Grain yield of 1.5 tons ha ${ }^{-1}$ was obtained with 20 tons ha ${ }^{-1} \mathrm{PM}+80$ $\mathrm{kg} \mathrm{ha}^{-1} \mathrm{P}_{2} \mathrm{O}_{5}$ followed by 20 tons ha-1 $\mathrm{PM}+60 \mathrm{~kg} \mathrm{ha}^{-1} \mathrm{P}_{2} \mathrm{O}_{5}$ (1.41 tons ha $\left.{ }^{-1}\right)$.

\section{CONCLUSION}

The study revealed that popcorn responded well to different rates of single superphosphate (SSP) added to 20 tons ha $^{-1}$ poultry manure. The soil properties at the end of the experiments improved in terms of O.M, total $\mathrm{N}$, available $\mathrm{P}$ and CEC. 20 tons ha ${ }^{-1} \mathrm{PM}+80 \mathrm{~kg} \mathrm{ha}^{-1} \mathrm{P}_{2} \mathrm{O}_{5}$ is recommended for optimum popcorn production in Kuru - Jos.

\section{REFERENCES}

[1] Akintola, S. O (1977). Maize Production Contraints and Improvement in Niger.The Maize Association in Nigeria. Ibadan. Pp. 223 - 232.

[2] Brady, N. C. (1984). The Nature and Properties of Soil. Macmillan: New York.

[3] Bruce, R. C., and Rayment, G. E. (1982). Analytical Methods and Interpretations used by the AgriculturalChemistry Branch for Soil and Land use Survey.Queensland Department of Primary Industries. Bulletin QB8 (2004), Indooroopilly, Queensland.

[4] International Institute of Tropical Agriculture (IITA), (2007).Crop Improvement.Division Activity Report and World Plan. Ibadan, Nigeria. Pp. 75.

[5] Kamprath, E. J. (1970). Exchangeable at as a Criterion for Limiting Leached Mineral Soils. Proceedings of Soil Science Society of America 34: 254 - 256.

[6] Kandil A.A., A.E. Sharief, A.N.Ramadan, P.(2017). Behaviors of Some Soybean Cultivars (Glycine max L.) Yield to Planting Dates and Different Phosphorus Fertilizer Rates. International Journal of Environment Agriculture and Biotechnology(ISSN: 2456-1878).2(6), 3202-3212.10.22161/ijeab/2.6.55

[7] K. Moustarhfer, N. Saber, H. Mohcine, C. Marrakchi, P.(2017).Fertility of agricultural soils in the area of Jorf Lasfar (El Jadida-Morocco). International Journal of Environment Agriculture and Biotechnology(ISSN: 2456-1878).2(1), 046-055.10.22161/ijeab/2.1.8

[8] McKenzie, N. J., Jacquier, D., Isbel, R. and Brown, K. (2004). Australian Soils and Landscapes - An Illustrated Compendium (CSIRO Publishing: Melbourne).

[9] Moody, P. W. and Bolland, M.D.A(1999).Phosphorus. In Soil Analysis: An Interpretation Manual; (Eds K. I. Peverik, I.A. Sparrow and D.I. Renter) (CSIRO Publishing: Melbourne).

[10] O.B., B., K.J, O., M.O, A., \& Y.A., B. (2017). Impact of Rotten Cocoa POD on Soil Microorganisms from Ikeji-Arakeji Metropolis, Osun State, Nigeria. International Journal Of Horticulture, Agriculture And Food Science, 1(4), 24-28. doi: 10.22161/ijhaf.1.4.4

[11] Obi, I.V. (1991).Maize, its Agronomy, Diseases, Pest and Food Values. Optimal Computer Solution Ltd. Enugu $208 \mathrm{P}$. 
Table.1: Chemical Properties of Soil Before and After Treatment in 2013

\begin{tabular}{lllllll}
\hline Properties & $\begin{array}{l}\text { Before } \\
\text { planting }\end{array}$ & $* \mathbf{T}_{\mathbf{1}}$ & $\mathbf{T}_{\mathbf{2}}$ & $\mathbf{T}_{\mathbf{3}}$ & $\mathbf{T}_{\mathbf{4}}$ & $\mathbf{T}_{\mathbf{5}}$ \\
\hline $\mathrm{pH} \mathrm{H} \mathrm{H}_{2} \mathrm{O}$ & 5.20 & 5.40 & 5.40 & 5.30 & 5.40 & 5.40 \\
$\mathrm{O} . \mathrm{M}(\%)$ & 0.80 & 0.87 & 0.87 & 0.90 & 0.88 & 0.90 \\
Total N $(\%)$ & 0.70 & 0.80 & 0.09 & 0.09 & 0.10 & 0.15 \\
Available P $(\mathrm{ppm})$ & 15.00 & 15.00 & 15.20 & 16.20 & 16.20 & 18.00 \\
Exch. $\mathrm{Mg}(\mathrm{cmol} \mathrm{kg}$ & 0.60 & 0.67 & 0.80 & 0.78 & 0.78 & 0.80 \\
Exch. $\mathrm{Ca}\left(\mathrm{cmol} \mathrm{kg}^{-1}\right)$ & 2.84 & 2.90 & 3.0 & 3.01 & 3.01 & 3.00 \\
Exch. $\mathrm{Na}\left(\mathrm{cmol} \mathrm{kg}^{-1}\right)$ & 0.22 & 0.26 & 0.23 & 0.24 & 0.24 & 0.24 \\
Exch. K $\left(\mathrm{cmol} \mathrm{kg}^{-1}\right)$ & 0.24 & 0.23 & 0.30 & 0.32 & 0.32 & 0.30 \\
$\mathrm{CEC}\left(\mathrm{cmol} \mathrm{kg}^{-1}\right)$ & 10.20 & 12.20 & 12.80 & 14.20 & 14.20 & 15.20 \\
\hline
\end{tabular}

$* \mathrm{~T}_{1}=20$ tons ha ${ }^{-1} \mathrm{PM}+0 \mathrm{~kg} \mathrm{ha}^{-1} \mathrm{P}_{2} \mathrm{O}_{5}, \mathrm{~T}_{2}=20$ tons ha- ${ }^{-1} \mathrm{PM}+20 \mathrm{~kg} \mathrm{ha}^{-1} \mathrm{P}_{2} \mathrm{O}_{5}, \mathrm{~T}_{3}=20$ tons ha-1 $\mathrm{PM}+40 \mathrm{~kg} \mathrm{ha}^{-1} \mathrm{P}_{2} \mathrm{O}_{5}, \mathrm{~T}_{4}=20$ tons ha' $\mathrm{PM}^{-1}+60 \mathrm{~kg} \mathrm{ha}^{-1} \mathrm{P}_{2} \mathrm{O}_{5}$, and $\mathrm{T}_{5}=20$ tons ha- $\mathrm{PM}^{-1}+80 \mathrm{~kg} \mathrm{ha}^{-1} \mathrm{P}_{2} \mathrm{O}_{5}$.

Table.2: Chemical Properties of Soil Before and After Treatment in 2014

\begin{tabular}{lllllll}
\hline Properties & $\begin{array}{l}\text { Before } \\
\text { planting }\end{array}$ & $* \mathbf{T}_{\mathbf{1}}$ & $\mathbf{T}_{\mathbf{2}}$ & $\mathbf{T}_{\mathbf{3}}$ & $\mathbf{T}_{\mathbf{4}}$ & $\mathbf{T}_{\mathbf{5}}$ \\
\hline $\mathrm{pH} \mathrm{H} \mathrm{H}_{2} \mathrm{O}$ & 5.30 & 5.40 & 5.50 & 5.50 & 5.50 & 5.50 \\
$\mathrm{O} . \mathrm{M}(\%)$ & 0.83 & 0.90 & 0.92 & 0.90 & 0.91 & 0.99 \\
Total N (\%) & 0.09 & 0.10 & 0.20 & 0.22 & 0.30 & 0.35 \\
Available P (ppm) & 15.20 & 15.00 & 15.60 & 16.00 & 17.20 & 17.00 \\
Exch. $\mathrm{Mg}(\mathrm{cmol} \mathrm{kg}$ & & 0.98 & 0.99 & 1.00 & 1.20 & 1.20 \\
Exch. Ca $\left(\mathrm{cmol} \mathrm{kg}^{-1}\right)$ & 0.99 & 2.90 & 3.00 & 3.00 & 3.50 & 4.00 \\
Exch. Na $\left(\mathrm{cmol} \mathrm{kg}^{-1}\right)$ & 3.00 & 0.20 & 0.20 & 0.22 & 0.21 & 0.22 \\
Exch. K $\left(\mathrm{cmol} \mathrm{kg}^{-1}\right)$ & 0.23 & 0.35 & 0.38 & 0.38 & 0.40 & 0.40 \\
CEC $\left(\mathrm{cmol} \mathrm{kg}^{-1}\right)$ & 0.38 & 15.20 & 15.00 & 16.00 & 15.80 & 16.00 \\
\hline
\end{tabular}

$* \mathrm{~T}_{1}=20$ tons ha ${ }^{-1} \mathrm{PM}+0 \mathrm{~kg} \mathrm{ha}^{-1} \mathrm{P}_{2} \mathrm{O}_{5}, \mathrm{~T}_{2}=20$ tons ha ${ }^{-1} \mathrm{PM}+20 \mathrm{~kg} \mathrm{ha}^{-1} \mathrm{P}_{2} \mathrm{O}_{5}, \mathrm{~T}_{3}=20$ tons ha- $\mathrm{PM}+40 \mathrm{~kg} \mathrm{ha}^{-1} \mathrm{P}_{2} \mathrm{O}_{5}, \mathrm{~T}_{4}=20$ tons ha ${ }^{-1} \mathrm{PM}+60 \mathrm{~kg} \mathrm{ha}^{-1} \mathrm{P}_{2} \mathrm{O}_{5}$, and $\mathrm{T}_{5}=20$ tons ha- $\mathrm{PM}+80 \mathrm{~kg} \mathrm{ha}^{-1} \mathrm{P}_{2} \mathrm{O}_{5}$.

Table.3: Effects of Treatment on the Number of Cobs and Grain Yield of Popcorn in 2013 and 2014 Cropping Season

\begin{tabular}{lcccc}
\hline & \multicolumn{2}{c}{ Number of cobs } & \multicolumn{2}{c}{ Grain Yield (tons ha-1) } \\
Treatments & 2013 & 2014 & 2013 & 2014 \\
\hline 20 tons ha $^{-1} \mathrm{PM}+0 \mathrm{~kg} \mathrm{ha}^{-1} \mathrm{P}_{2} \mathrm{O}_{5}$ & 15 & 10 & 0.14 & 0.05 \\
20 tons ha $^{-1} \mathrm{PM}+20 \mathrm{~kg} \mathrm{ha}^{-1} \mathrm{P}_{2} \mathrm{O}_{5}$ & 25 & 21 & 0.80 & 0.70 \\
20 tons ha $^{-1} \mathrm{PM}+40 \mathrm{~kg} \mathrm{ha}^{-1} \mathrm{P}_{2} \mathrm{O}_{5}$ & 36 & 34 & 1.20 & 1.01 \\
20 tons ha $^{-1} \mathrm{PM}+60 \mathrm{~kg} \mathrm{ha}^{-1} \mathrm{P}_{2} \mathrm{O}_{5}$ & 38 & 35 & 1.70 & 1.41 \\
20 tons ha $^{-1} \mathrm{PM}+80 \mathrm{~kg} \mathrm{ha}^{-1} \mathrm{P}_{2} \mathrm{O}_{5}$ & 38 & 36 & 1.94 & 1.50 \\
\hline FLSD $(\mathbf{p} \leq \mathbf{0 . 0 5})$ & 12 & 9.0 & 0.39 & 0.22 \\
\hline
\end{tabular}

